\title{
Diverse Participation and Orderly Guiding: The Establishment Policy Strategies of the Community Socialized Elder Care Service System in Shanghai, China
}

\author{
Kai Yu \\ School of Social Sciences, Shanghai University of Engineering Science, Shanghai, China \\ Email: ykham1999@163.com
}

Received 22 June 2014; revised 6 August 2014; accepted 21 August 2014

Copyright (C) 2014 by author and Scientific Research Publishing Inc. This work is licensed under the Creative Commons Attribution International License (CC BY). http://creativecommons.org/licenses/by/4.0/

(c) (i) Open Access

\begin{abstract}
With the acceleration of aging population trend and the further development of market economy system, it is the establishment and improvement of urban communities Socialized Elder Care Service System participated by pluralistic entities that has become the basic strategies in current China to deal with the problem of aging population. From the policy empirical research of social forces participated in Community Socialized Elder Care Service (CSECS) System in Shanghai recent years, this paper reveals the role positioning, basic functions and the interaction of the government, society organizations, citizens and other bodies which participated in the process of CSECS System establishment currently. And then, by analyzing external barriers and internal constraints faced by this social elder service system, this paper puts forward some suggestions to improve it. This study will be important theoretical value and practical significance for the construction and improvement of SCECS with Chinese characteristics policy pattern based on the positive interaction of "government-society-family".
\end{abstract}

\section{Keywords}

Community Socialized Elder Care Service (CSECS) System, Aging Population, Policy Strategy, Pluralistic Participants, Shanghai

\section{Introduction}

Basing on the standard of aging population developed by the UNs, China has entered the "aging” society on the 
whole since 1999. As one of the earliest metropolis to enter the aging times in China, Shanghai was approximately 20 years earlier to enter Old Ageing Society than the national level. It estimates that the Shanghai aging population would achieve its peak level about the year of 2030 and the aging population will be $35 \%$ of the total population. With the acceleration of aging population, the elderly population base in the proportion of the population is increasing. With the reduction in family size and the sharply increasing of advanced aging and the empty-nest elders who are loss or semi-loss ability, the traditional family elder care function is weakening gradually. Therefore, the task to strengthen the social elder care service system is very urgent and important. Especially in Shanghai, the pressure of socialized elder care construction is heavier than other cities.

In historically, the policy called "Making a Reality of Community Care" was originated from UK, adopted by government of Margaret Thatcher since 1980s. Compared with the traditional family care or Institutional care, community care has many advantages of domiciled care. From the experiences of Europe-American developed countries, building community elder service system is the best way to effectively deal with the aging population crisis, which has increasingly become the biggest consensus of contemporary society.

There are many of important research results about the community elder care policy strategic analysis in international academia over the past three decades, such as A. Walker [1], Davies, B.P. [2] and Isobel Allen [3], etc. In China, when Chinese local governments have adopted many kinds of policy to building the community old service system in the last decade, there are many scholars to pay their close attention about the elder care themes. Some scholars, such as Wang Xupu [4], Xiong Bijun [5], Liu Xiaojing \& Zhang Jiliang [6], Chen Yuguang [7], Zhang Zhongbing \& Xu Xian [8], etc., had discussed the general principle or local practical experiences of the community elder care server system, but there are still fewer papers to discuss the elder care server system construction policy strategy in Shanghai. So in this paper, from the perspective of Social Policy Analysis, the author will systematically analyze the policy strategies and influences of Shanghai's community elder care server system building. It will be beneficial to understand the realistic meaningfulness of the Chinese characteristic community care policy.

\section{The Situation and Characteristic of Aging Population in Shanghai}

\subsection{The Situation of Aging Population in Shanghai}

According to the latest statistical information about the aging business and the aging population monitoring made by Shanghai Civil Affairs Bureau [9], the total amount of the aging population over the age of 60 in Shanghai had reached 3.876 million for $27.1 \%$ of the total population with city household by the end of 2013, which is much higher than the national average of $15 \%$. Meanwhile, the people of $65+$ years in Shanghai were over 2.566 million that accounted for $17.9 \%$ of the total population in Shanghai; $70+$ years older ageing were 1.719 million that accounted for $12.0 \%$ of the total population. The senior citizens of $80+$ were over 0.715 million that accounted for $18.5 \%$ of the elderly population aged 60 and over, which accounted for over $5 \%$ of the total population in Shanghai.

\subsection{The Characteristic of Aging Population in Shanghai}

Overall, in term of the monitoring statistics information of aging population and the affairs of aging Shanghai Committee on Aging (form 2009 to 2013) [10], the current situation of population aging in Shanghai generally has the following characteristics:

1) The proportion of aging population in urban household population continues to increase in recent years. From 2009 to 2013, the proportion of ageing population over 60 in Shanghai City's population annual growth rate was over 5.3\% per year, which is far exceeding the 3\% per year average level of China.

2) Social dependency ratio of aging population continues to grow year by year, and the life expectancy continues to extend simultaneously. By the end of 2013, the dependency ratio of aged 60 and over was 42.4, an increase of $3.0 \%$ over the previous year. At the end of 2013, aged 70 and over accounted for $44.4 \%$ in Shanghai total aged population over 60 years in Shanghai, and people of $80+$ accounted for $18.1 \%$, too. So, the demand for social elder care \& server is rising. This condition would give the Community Elder Care Service long-term and sustained pressure; meanwhile, it also brings the development opportunity for those younger elders who are to be mobilized to participate in elder care and services.

3) The numbers of empty nesters family and the alone-living aging people are increasing quickly. With 
the family structure miniaturization trend, the 4-2-1 family type became the mainstream family structure in China, and the parents of one-child began to enter old age in recent years. By the end of 2013, the population of elders who living alone in Shanghai had reached 9.043 million (including 0.25 million of 80+ alone-living elders people), and the solitary old people was over 0.235 million, and the risk in their senectitude is increasing. As a result, the community elder care system in Shanghai are confronted with numerous difficulties and serious challenges.

4) The regional distribution and growth rate of aging population in Shanghai are becoming more and more imbalance and complex. Firstly, the overall proportions of aging population in districts of Shanghai are more than $23 \%$, but the proportion in the center city is much greater than that of the suburbs. On the other hand, along with the residents continues to move from the city center to suburb recent years, the absolute number of aging population in center city is decreasing, and the aging speed of aging population in suburbs is faster than the center city, and absolute number of elder population in suburbs is increasing. Because of those problems, there is further complexity of the community elder care system construction in Shanghai.

\section{Government-Led and Social Participation: The Basic Policy Strategy Responding to the City Aged-Maintenance Crisis in Shanghai}

According to the above-mentioned condition and characteristic of aging population in Shanghai, Shanghai government has put forward the basic policy strategy to deal with the challenge of aging in generally, namely the "90-7-3" composite structure: $90 \%$ of the aging population-based on home care, $7 \%$ living in families but accept the community help and $3 \%$ choose the ageing nursing agents. It is a strategic development direction of urban elder service system built under the real background of family elder care function weakening and institutional care supply insufficient [11]. Therefore, Elder Care System on the core of the residential community is the key. Since 2006, Shanghai has begun to build the community elder care system led by the governments and supposed by social organization. In this process, government-led and social participation are the basic policy strategy of responding to the city aged-Maintenance crisis in Shanghai.

Community care was defined in the Britain White Paper Caring for People: Community Care in the Next Decade and Beyond (Department of Health, 1989) [12], which means that elder people can enjoy the care which serves to keep people in the community and out of residential care. According to the policy practices in Europe and the US, This system can provide life care, health care, medical care and other essential community social services for ageing. There is a good elder care service pattern adapting to the current situation of the aged population in modern society [13].

Shanghai Community Social Elder Care Services (CSECS) system is a family-centered, community-based pattern services system with home care system as a carrier and institutional elder care services as supplementary, which originated from the concept of Community Care. In order to construct the CSECS system, Shanghai was mainly focused on those points as follows:

\subsection{Building Community Elderly Care Services Agencies and Facilities to Provide Support to Socialized Elderly Care}

Focus on government's practical projects and on the basis of community resources, Shanghai has built 340 agents for the elderly daytime service at the end of 2013, which proved care service for a total of 12,000 old peoples; And also built 230 community old age help service agents, which serviced 0.282 million old people throughout the year; And also built 553 community Meal Help Service Agents, the direct beneficiary were about 0.06 million per year.

\subsection{Raising Community Elder Care Funds by Multi-Subjects}

In order to protect the living alone empty nest, the old people of abilities-loss \& low-income and other frail senior citizens with specialized care service organizations to provide care, housekeeping services, rehabilitation care, health care and other services. In 2009, Shanghai raised fiscal funds 40 million Yuan and 10 million Yuan welfare lottery for the elder-bed subsidies; 255 million Yuan subsidy funds were distributed to home care services throughout the year, including welfare lottery fund 20 million Yuan and financial funds 235 million Yuan, 
and the beneficiaries were 0.129 million. In addition, the construction of community elder care service system also supplemented by districts government and sub-districts matching funds.

\subsection{Enhancing Efforts to Support the Elder Care Institutions and Increasing the Elder Care Beds \& Medical Beds}

By the end of 2013, there were in total 631 Nursing Institutions in Shanghai, in which 317 was Government organized and 314 was society organized; The numbers of elderly medical institutions (independent nursing homes, elderly hospital) are reached 25, the numbers of institution elder nursing beds amounted to 108,364 (in 2011 the number is 101,896). At the end of 2103, there involves a total of 49,700 family elderly beds in Shanghai (less 19,000 beds than 2011).

\subsection{Mobilizing Social Organizations and Social Resources Pluralistic Participation in Building Community Elder Care Service System}

Since the 1980s, with the rise of "Global Associational Revolution", social organizations has been regarded as the "third sector" beyond the government forces and market forces; In China, the NGOs have been playing more and more important role in the process of building social elder service system [14]. In 2009, Shanghai government held a meeting on social construction, and an explicit proposal was mentioned that the dominant position of the social organizations should be fully played in the social construction, and policy support should be provided for the full mobilization of the social organizations, involved in social care service fields. Shanghai has explored and tried much in this field, including:

1) Changing the management mode of social organization. Relax the registration threshold of social organizations in the field of community elder care, relief, charity, and social work, etc., especially encourage social organizations to participate actively in community services for the elder care.

2) Strength functions of the government transference. Take the form of services government procurement and encourage social organizations substantial participation in the community elder care service. Currently, all district governments of Shanghai have a special public fund to buy CECS for the lonely elder resident, and launched the relevant provisions of the management.

3) Introducing the concept of venture Philanthropy, assists the elder care NGOs to develop their specialized abilities. Shanghai Civil Affairs Bureau selected excellent and innovative socialized elder care service projects to nurture and support, and guided the society organizations to provide their personalized and professional elder care service to deal with the different needs of the community elder people. In 2010, Shanghai municipal government allocated 15 million Yuan for lottery funding and supporting public service projects and public service organizations aiming at "help the older, the disabled, the orphans and the poor". 65 projects were selected by the form of public welfare investment creation including 17 elder care projects accounting for $26 \%$ of the total; and 35 public welfare investment creation projects were selected including 13 elder care projects accounting for $37 \%$ of the total. Community elder care project has become a focus in civic welfare investment creation field.

4) Vigorously support the older institutions and encourage older persons to participate in community self-help and mutual aid community elder care system. Currently, there are City Senior Associations and the elder foundations at the municipal level, 176 senior associations and 107 senior sport associations together 13,100 registered senior artistic groups with 0.31 million people involved in activities.

\section{The Role Positioning and Interaction Relationship of Multiple Subjects in Shanghai CSECS System}

The policy strategies of the CSECS system construction in Shanghai is a continual process coordinated with the transition of the service-oriented government, and also means some actively explorations of new social governance. There are some important Multiple subjects such as government, social organizations, family and the citizen, etc. All of them participated in the community elder care service, and initially formed a coordinated interaction of the main relationship which effective integrates the multiple resources in community elder care services fields, which represents the future development trend of socialized elder care service system in Chinese. 


\subsection{The Role Positioning and Functions Involved of Multiple Subjects in Shanghai CSECS System}

According to Shanghai practices, we can conclude the role positioning and basic functions involved in the main Participants in community elder care field as Table 1.

Broadly speaking, there are three roles positioning involved in the main participants at the following:

Firstly, the government, as the system designer and policy maker, the municipal financial supporter and public services buyer, is the decisive factor to construct this system, and play a core and guide roles. The basic functions of government include institutional formulation and policy design, policies supporting of multiple subjects participation in the Community Elder Care Services, and the purchase of public care services for community elder people.

Secondly, social organizations are the main operator and performer of socialized elder care affairs, their basic functions are about the day-to-day management of the social community elder care affairs, the provision of social community elder care service, and hatching society organizations.

Thirdly, community neighborhoods are volunteer participants for community elder care services, as the volunteers to participate in societal elder care services, they are self-helpers and helpers of others in community elder care services.

\subsection{The Characteristics of Shanghai CSECS System}

This kind of Community-centered social elder care service model learns and absorbs the European and American communities care experience, combined with Chinese own national conditions and social conditions and plus some appropriate innovations has formed a leading role in the of governments at all levels [15]. Various types of participants are effectively integrated through public financial support, social policy support and other paths by governments, and also need initiative participation of kinds of social organizations. All participants' effective labor division and societal resources are basically realized system integration. Thus made the arrangement has distinct Chinese characteristics [16].

Mainly, in the multi-participated CSECS system of Shanghai, there are two basic spaces for the elder people: one is the family spaces for living, and another is the social space for human communication \& social support. From experience of shanghai, the resident community is at the core of the older people's living space, thus integrates all kinds of social server resources to make an effective social support network for older people. Such an Arrangement takes account of elder person's essential living \& social demands, which covers the triple functions of community elder care: 'care in the community, care by the community, and care with the community'

Table 1. Main participant's role positioning and basic functions in Shanghai CSECS system.

\begin{tabular}{|c|c|c|}
\hline Participants & Role Positioning & Basic Functions \\
\hline Government & $\begin{array}{l}\text { Elder care system designers } \\
\text { Social policy maker } \\
\text { Public financial supporter } \\
\text { Public elder services buyer }\end{array}$ & $\begin{array}{l}\text { 1. Institutional formulation and policy design } \\
\text { 2. Financial and hardware (facilities) supports } \\
\text { 3. Prove policies, to support multiple subjects to participate } \\
\text { in the pension services } \\
\text { 4. The purchase of community elder care of public services } \\
\text { (fixed-point direct purchase, hosting, public welfare } \\
\text { investment creation) } \\
\text { 5. Organizing, managing and monitoring the elder care } \\
\text { servers }\end{array}$ \\
\hline $\begin{array}{l}\text { Social Organization } \\
\text { (Including elder care } \\
\text { institutions, elder server } \\
\text { enterprises, \& NGOs, etc.) }\end{array}$ & $\begin{array}{l}\text { The operator of socialized elder care affairs } \\
\text { The performer of community elder server }\end{array}$ & $\begin{array}{l}\text { 1. Assume the day-to-day management of the social elder } \\
\text { service affairs. } \\
\text { 2. Provide professional services for elder people. } \\
\text { 3. Supply public server procured by government. } \\
\text { 4. The incubator of professional social elder care } \\
\text { organization }\end{array}$ \\
\hline $\begin{array}{l}\text { Community neighborhoods } \\
\text { (including the elder family, } \\
\text { neighbor, and other volunteer } \\
\text { citizens ) }\end{array}$ & $\begin{array}{l}\text { The basic living unit for elder people. } \\
\text { The Volunteer participants for Community elder } \\
\text { care Services }\end{array}$ & $\begin{array}{l}\text { 1. Provide basic space for the elders in a family unit. } \\
\text { 2. Volunteer to participate in social elder care services. } \\
\text { 3. Self-helper and helper of others in community elder care } \\
\text { services } \\
\text { 4. Social supervisor of service provided Society } \\
\text { organizations }\end{array}$ \\
\hline
\end{tabular}


[17] and got good results to fit best with the elder people's daily life. So we can conclude 3 characteristics of Shanghai socialized elder care system as follows:

1) Community is not only the basic social space for the elder daily life, but also the basic unit for government social governance, and the basic active domain for social organizations. Shanghai elder social care system establishes community-centered, financial and material resource fully mobilized at all levels of government construction. In sub-district level to build community elder care service centers and in the neighborhood committee level to build elder activity rooms and elderly day-care care centers which can carry out the "six help" services for elder. This arrangement roughly can fit the overall situation of Shanghai elder care system demands and differentiation requirements, also fully mobilizes and integrates a variety of social forces to crack the aging crisis.

2) The government's policy support is the main driving force to promote the construction of the CSECS system. Government no doubt holds a dominant position of building the system. In this process, all levels of government give financial, material resources and policy support, and also fully use government public services purchasing, public welfare investment creation and other innovative forms to support the social organizations to involve it.

3) The full mobilization and broad participation of social organizations and community residents is the important starting point to build CSECS system. Social organizations can effectively restore municipal services in "government failure" and "market failures" abuses. The situation of organizations own development and establishment and civic participation and volunteer awareness are important parts in the socialized community elder care service system. In addition, Shanghai has also been advancing the community residents to participate in the way of mutual help and elder community volunteers' service network through the development of younger elder volunteer service and mobilizing community residents' participation.

\section{The Barriers and Problems of CSECS System in Shanghai Are Faced}

No doubt, the current construction of socialized pension service system in Shanghai has achieved remarkable results; its development direction also fits social development trends and response to the future aging trend. But at the same time, we should note further that there still exist some internal and external constraints in Shanghai CECS system. In general, some problems still exist in establishing socialized community elder care service system as follows:

1) The incomplete transformation of government functions and weak on-the-whole design capabilities of community social elder care policy. On one hand, the responsibilities and convergence among three divisions of governments (the municipality, the district (or county) and sub-district) have a lot of loopholes and lack the legal system. On the other hand, there are three types of means to build this system: the administration in the process of transformation of government functions, the policy co-ordination and comprehensive applies the ability of government departments and purchase services supporting management policies for improvement of social organizations. How to prepare and play the complementary relationship of those three means are still facing much greater challenges.

2) The source of funding of community socialized elder care is still relatively simple, the immobilized financial investment criteria and supporting pattern by three levels of governments has fallen far behind growth and changes of ageing population. For example, with the accelerating population movements and increasing suburb population in recent years, the spatial differentiation of ageing population forms huge changing, but there is no scientific public fund financial transfer payment policy to deal with those changes to the new unbalance of the public elderly services supplies. The convenience and accessibility of community elder care; home care and community hospital beds and other sectors in the new population import areas are still shortage.

3) The coordination function of the principal bodies is still not smooth. Affected by the existing institutional and administrative fragmentation, various bodies which are involved in the community elder care services came from different apartments, the supply of community elder care and social benefits are still belong to different authorities, and the source of funds are different from each other. It is prone to "fragmented" and resulting in lower efficiency in community services.

4) The autonomy and professionalization of the social elder server organizations are still seriously weak. It now seems that Most of the NGOs to provide social elder servers are small and loose, which seriously restricts the upgrade of its service level. 


\section{The Policy Suggestions to Improve the CSECS System in Shanghai}

Therefore, strengthening the system construction and optimizing policy convergence can really crack the bottleneck of the CSECS system. There are some suggestions as follows:

1) Further clarifying functions and convergence of government of all levels. Co-ordinate socialized elder care goals and effectively enhances the system coordination ability of socialized elder care policy.

2) Improving and perfecting public finance transfer payments for the regional population changing trends. Enhance the public finance transfer payments and improve the relevance and effectiveness of public financial investment.

3) Optimizing the supply mechanism of community elder care services. Perfect the contract bids of the government purchasing public elder services, financial subsidies, process monitoring and outcome evaluation of public finance policies, to ensure the stability increased of the supply level and quality of socialized elder care service.

4) Increasing efforts to hatch the social organizations. According to scientific, professional and specialized requirements, focus on strengthening the establishment of professional capacity of social organizations and effectively improve their supply capacity for elder care service.

5) Unearthing the Chinese traditional filial piety culture and promote residents volunteers to participate in the community services for elder care. Around the "shared" principle of elder community care, with highlighting goals of the elder social reintegration capacity establishment, unearth the Chinese traditional filial piety culture, and promote younger elder and residents volunteers to participate in the community services for elder care and emotional communication providing conditions, etc.

\section{Conclusions}

In general, Shanghai's strategy to fully mobilizing multiple social entities for aging service system in urban communities is a good attempt to cope with the crisis of aging population. This practice clearly defines the roles, the basic functions and interactive relationship of multiple subjects in the community elder service system construction. It's helpful to promote social organizations active in community elder care service. This approach has significant practical value to improve a benign interaction among the "government-society-market" triangle in the process of China's social management transformation.

In order to make a more balanced and user friendly community aged service and to raising more elderly welfare, in the further, Shanghai still should take measures to further transformation of government functions, cultivate social organization, strengthen the public financial investment, and optimize the community service supply mechanism for elder people.

\section{Acknowledgements}

This article was supported by the funding of Shanghai Middle-Aged and Young Teachers in Colleges and Universities Abroad Project.

\section{References}

[1] Walker, A. (1982) Community Care: The Family, the STATE, and Social Policy. Martin Robertson, Oxford.

[2] Davies, B.P. and Challis, D.J. (1986) Matching Resources to Needs in Community Care: An Evaluated Demonstration of a Long-Term Care Model. Gower, Aldershot.

[3] Allen, I., Hogg, D. and Peace, S. (1992) Elderly People: Choice, Participation and Satisfaction. Policy Studies Institute, London.

[4] Wang, P.X. and Lester, M.S. (2010) Outsourcing Government-Financed Social Services to Civil Society Organizations: Lessons from China and Abroad. Peking University Press, Beijing, 6.

[5] Xiong, B.J. (2007) The Pattern of Home Care and Community Care in the Era of Aging. Journal of Shanghai Polytechnic College of Urban Management, 4, 51-53.

[6] Liu, X.J. and Zhang, J.L. (2013) The Idea, the Path and Countermeasures of China's Elder Service System Construction. Journal of Hebei, 2, 123-127.

[7] Chen, Y.G. (2013) Community Elder Service System Construction: International Experience and Basic Path. Expanding Horizons, 2, 76-78. 
[8] Zhang, Z.B. and Xu, X. (2014) Research on the Safeguard Mechanism of Elder Service System. Journal of Hunan Social Science, 2, 8-112.

[9] Shanghai Aging Committee (2014) The Monitoring Statistics Information of 2013 Aging Population and the Affairs of Aging. http://www.shanghaigss.org.cn/news_view.asp?newsid=9614

[10] Shanghai Aging Committee (2014) The Monitoring Statistics Information of Aging Population and the Affairs of Aging (2009-2013). http://www.shanghaigss.org.cn/news_more.asp?lm=212

[11] Jing, Y.J. and Chen, R.J (2009) The Development and Manage Innovation of China's Home Elder Service System: In View of Collaboration. Fudan Journal (Social Sciences), 5, 133-140.

[12] Department of Health and Department of Social Security in British (1989) Caring for People: Community Care in the Next Decade and Beyond. Cm.849. HMSO, London.

[13] Gu, L.M. (2008) The Comparative Study of Public Service Models of Britain, The United States and Singapore. Zhejiang Academic Journal, 5, 107-112.

[14] Lester, M.S. (2002) Global Civil Society: The Views of Nonprofit Sectors. Social Sciences Academic Press, Beijing.

[15] Ye, C., Xu, K., et al. (2009) The Study of NGOs’ Temporary Issues. China Science and Technology University Press, Hefei.

[16] Shi, N.C. (2009) The Research Anthology of Exploration and Practice to Solve Problems—Shanghai New Economic Organizations and New Social Organizations. SDX Joint Publishing Company, Shanghai.

[17] Cai, H.X. (2000) Social Work Dictionary. 4th Edition, Domestic Ministry of Community Development Magazine, Taipei. 
Scientific Research Publishing (SCIRP) is one of the largest Open Access journal publishers. It is currently publishing more than 200 open access, online, peer-reviewed journals covering a wide range of academic disciplines. SCIRP serves the worldwide academic communities and contributes to the progress and application of science with its publication.

Other selected journals from SCIRP are listed as below. Submit your manuscript to us via either submit@scirp.org or Online Submission Portal.
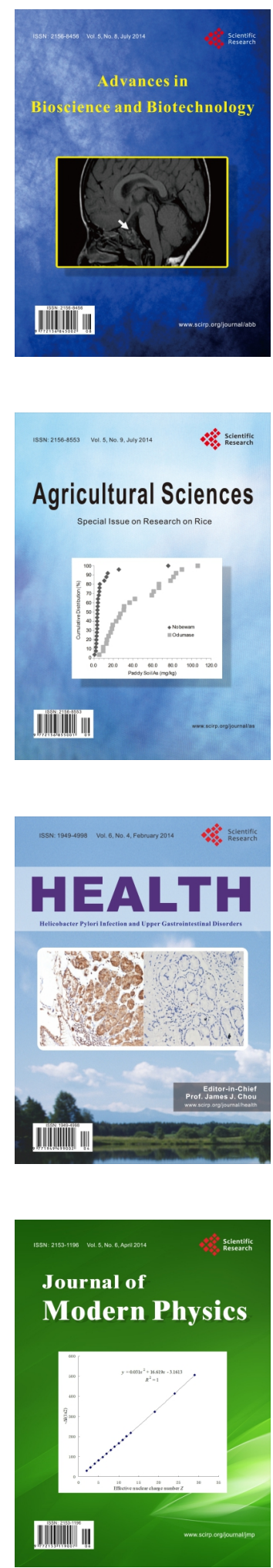
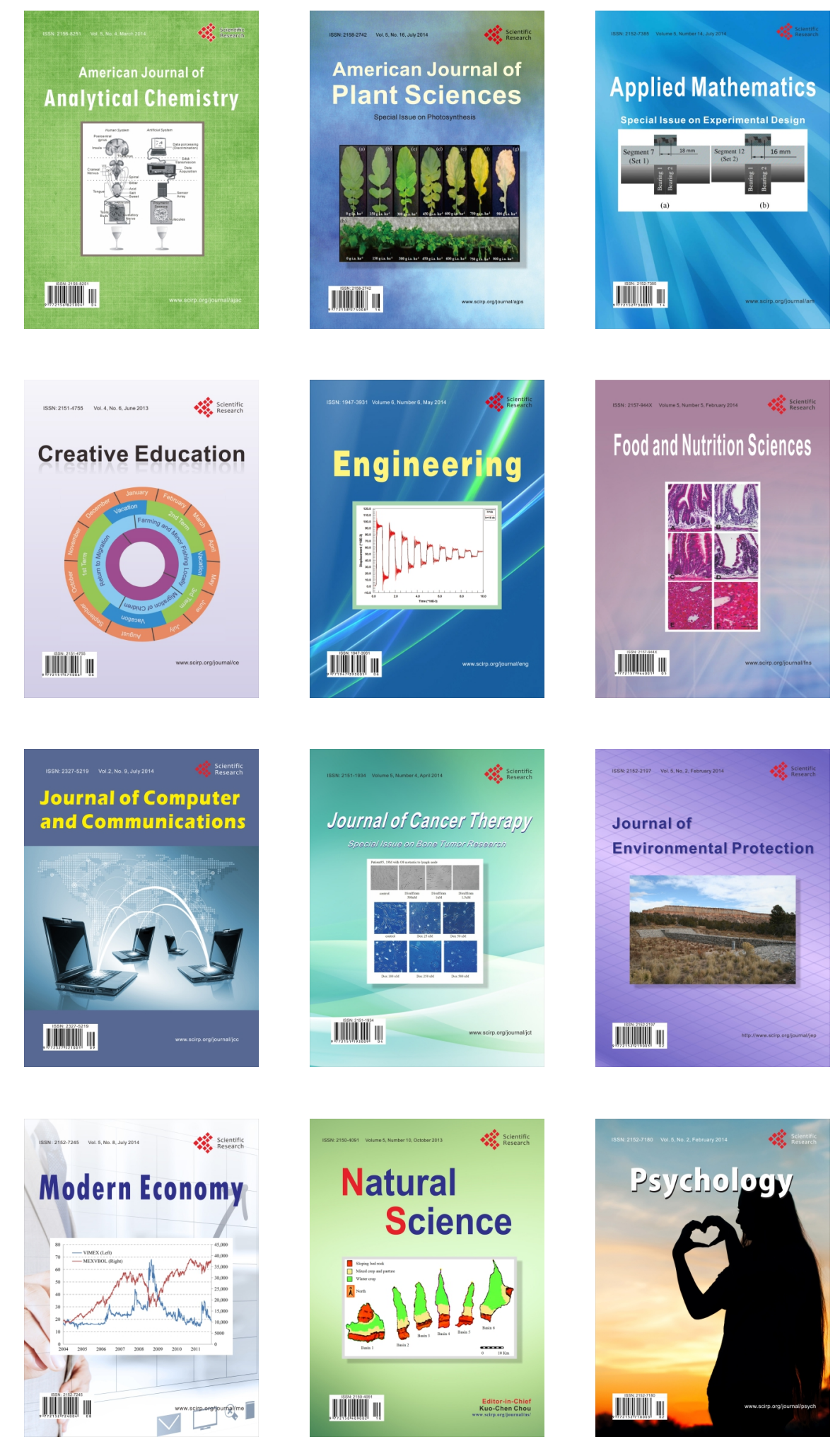